blindness", Report on IAPB conference, Argentina.

5. Lemp MA (2015), "Report of the National Eye Institute/Industry Workshop on Clinical Trials in Dry Eye". CLAO J. 21: p. 221 - 232.

6. Lyndon $\mathbf{W}$. Jones, Laura Downie, Donald Korb, et al (2017), "TFOS DEWS II management and therapy report", DEWS 2017, The Ocular Surface. 15(3): p. 163 - 178.

7. Bộ Giáo dục và đào taoo (2008), "Công tác chăm sóc mắt trong hệ thống trường học", Khuyến cáo của Hội thảo Quốc gia ngày 18/12/2008.

8. Trân Thị Tuyết Nhung (2005), "Đánh giá sự chế tiết nước mắt qua môt số test lâm sàng trên một nhóm người Việt Nam trưởng thành", Luận vằn thac sỹ Y học, Trường Đai họ Y Hà Nô̂i.

9. Schaumberg DA, Sullivan DA, Buring JE, Dana MR (2013), "Prevalence of dry eye syndrome on US women". Am J Ophthalmol. 136(2): p. 318-326.

\title{
TÌM HIỂU MỐI LIÊN QUAN KIỂU GEN ICEA, CAGA, VACA CỦA HELICOBACTER PYLORI VÀ MÔ BỂNH HỌC Ở BÊ̂NH NHÂN UNG THƯ DA DÀYY
}

\author{
Trần Việt Hùng1, Trần Ngọc Ánh ${ }^{2}$, Nguyễn Quang Duật ${ }^{3}$, \\ Dương Quang Huy ${ }^{3}$, Hoàng Thị Thu Hà ${ }^{4}$, \\ Đỗ Thị Bích Ngọc ${ }^{4}$, Trần Tuấn Việt ${ }^{1}$, Trần Văn Phú ${ }^{5}$
}

\section{TÓM TẮT}

Đă̆t vấn đề: Sự kết hợp H.pylori và UTDD cùng với sự gia tăng tỷ lệ lây nhiểm trên toàn thế giới, cho thấy sự cấp thiết của việc tìm ra các chiến lược phòng ngừa bệnh. Việt Nam hiện nay là một trong những nước có tỷ lệ nhiễm $\mathrm{H}$. pylori cao. Gene cagA, vacA được đặc biệt chú ý trong UTDD, và trong nước mới chỉ có một số nghiên cứu làm sáng tỏ một phần mối liên quan chủng $H$. pylori có cagA, vacA ở bệnh nhân UTDD. Tuy nhiên, cho đến nay còn ít nghiên cứu đề cập đến việc phân tích biểu lộ gen iceA liên quan với các gen cagA, vacA của $H$. pylori ở bệnh nhân ung thư dạ dày và mối liên quan của các gen này với tổn thương mô bênh hoc. Đối tương và phương pháp: Nqhiên cứu tiến cứu, mô tả cắt nqanq, có so sánh đối chứnq. Đối tương nghiên cứu: qồm 91 bênh nhân UTDD (nhóm bênh) và 92 bênh nhân viêm da dày man tính (nhóm chứnq), đước chon tronq số nhữnq nqười đã đến nôi soi da dày và đước chỉ đinh sinh thiết niêm mac da dày để chẩn đoán xác đinh tại khoa Thăm dò chức năng, Bênh viên Bach Mai. Kết quả: Các BN UTDD có hình ảnh MBH biệt hóa kém chiếm tỷ lệ cao nhất ở cả hai nhóm CagA và VacA dương tính là $55,4 \%$ và $54,5 \%$. Không có sự khác biệt các kiểu gẽn iceA1 và iceA2 giữa thể tuyến ống và thể tế bào nhẫn ở bênh nhân UTDD với $p>0,05$. Không có thể $\mathrm{MBH}$ tuyển chế nhày có $H$.pylori mang gene iceA. Kiểu gen iceA1 chiếm 54\% ở nhóm MBH UTDD biệt hóa kém,

\footnotetext{
${ }^{1}$ Bệnh viện Bạch Mai

${ }^{2}$ Đại học Y Hà Nọi

${ }^{3}$ Hoc viên Quân Y

${ }^{4}$ Viện Về sinh dịch tễ Trung ương

${ }^{5}$ Học viện Y Dược hoc cổ truyền

Chịu trách nhiệm chính: Trân Việt Hùng

Email: hungnoisoibm@gmail.com

Ngày nhận bài: 18.11.2020

Ngày phản biên khoa họ: 28.12.2020

Ngày duyệt bài: 6.01.2021
}

$32 \%$ ở nhóm biệt hóa vừa. Kiểu gene iceA2 chiếm $50 \%$ ở nhóm biêt hóa kém và $40 \%$ ở nhóm biêt hóa vừa. Sự khác biệt giữa các kiểu gene IceA1 và İce $A 2$ ở các nhóm $\mathrm{MBH}$ trên bênh nhân UTDD ở nhóm biêt hóa vừa và kém có ý nghĩa thống kê với $p<0,05$. Kết luận: Không có mối liên quan giữa các týp CagA, VacA; các kiểu gen với các đặc điểm mô bệnh học của ung thư da dày theo WHO năm 2010. Sứ khác biêt giữa các kiểu gen iceA1 và iceA2 ở các bệnh nhân ung thư da dày ở nhóm biệt hóa vừa và kém có ý nghĩa thống kê $(p<0,05)$.

Tư khóa: Gene cagA, kiểu gene vacA, kiểu gene iceA; Helicobacter pylori; ung thư dạ dày.

\section{SUMMARY \\ THE ASSOCIATION OF HELICOBACTER PYLORI ICEA, CAGA, VACA GENOTYPES RELATED WITH HISTOPATHOLOGICAL OF GASTRIC CANCER \\ Background: Gene cagA and vacA are particularly} noticeable in gastric cancer. There have been few studies on the analysis of iceA gene expression related to $H$. pylori cagA and vacA genes in gastric cancer patients. Patients and Methods: The objective of this study was to investigate the expression of $\mathrm{H}$. pylori with the iceA, cagA, vacA positive have relationship with histopathology of gastric cancer. Results: The gastric cancer patients with poor differentiated image accounted for the highest proportion in both cagA and vacA positive groups at $55.4 \%$ and $54.5 \%$. There was no difference in the iceA1 and iceA2 genotypes between tubular and ring cells in gastric cancer patients with $p>0.05$. It is not possible that the secretory contains $\mathrm{H}$. pylori that carries the iceA gene. The iceA1 genotype accounts for $54 \%$ in the poorly differentiated group, and $32 \%$ in the medium differentiated group. The iceA2 genotype accounts for $50 \%$ in the poorly differentiated group and $40 \%$ in the medium differentiated group. The difference between genotypes $A 1$ and $A 2$ in patients with gastric cancer in the moderately and poorly differentiated group was 
statistically significant with $\mathrm{p}<0.05$.

Keywords: cagA, vacA, iceA genotyps, Helicobacter pylori, gastric cancer

\section{I. ĐĂT VẤN ĐỀ}

Các nghiên cứu cho thấy mối liên quan chăt chẽ giữa ung thư da dày và $\mathrm{H}$. pylori; WHO đã công bố $H$. pylori là nguyên nhân nhóm I gây UTDD [1]. Sự kết hợp H.pylori và UTDD cùng với sư gia tăng tỷ lệ lầy nhiểm trên toàn thế giới, cho thây sự cấp thiết của việc tìm ra các chiến lược phòng ngừa bệnh. Tuy nhiên mối liên hệ giữa $\mathrm{H}$. pylori và UTDD thực sự phức tạp, theo một số nghiên cứu chỉ khoảng 1-3 cho đến dưới $20 \%$ BN có nhiễm $H$. pylori sẽ phát triển trở thành UTDD và tiệt trừ $\mathrm{H}$. pylori được coi là biện pháp then chốt trong điều trị u MALT [2].

Tại khu vức Đông Nam Á, các kiểu gene chiếm ưu thế khi gây bệnh của $\mathrm{H}$. pylori là cagA, vacA genotype s1-m1[3]. Gần đây, gene iceA được chú ý tới (là gene gây bệnh do cơ chế tiếp xúc với các tế bào biểu mô) và đã được đề xuất có liên quan với bênh viêm loét da dày. Gene iceA có hai biến thể alen chính, iceA1 và iceA2. Van Doorn et al [4] ghi nhận rằng các loại kiểu gen iceA là độc lập với tình trạng cagA và vacA, và có mối liên quan mât thiết giữa sự hiên diên của các gen iceA1 với bệnh loét dạ dày. Một số nghiên cứu đưa ra ý kiến rằng kiểu gen của iceA kết hợp cagA có thể làm tăng nguy cơ bênh nhân bị loét da dày tá tràng [5]. Thực tế là có sự khác biệt về địa lý trong cá kiểu gen vacA và iceA là điều thú vị. Kiểu gene iceA1 chiếm ưu thế ở Nhật Bản và Hàn Quốc, còn kiểu gene iceA2 chiếm ưu thế ở Hoa Kỳ và Colombia. Như vậy, kết luận thu được từ một khu vực duy nhất có thể không trùng lặp tại các khu vực khác. Hiện nay trong nước hãy còn ít nghiên cứu tìm hiểu mối liên quan của gen iceA với các gen cagA, vacA trên bệnh nhân ung thư dạ dày có nhiêm $\mathrm{H}$. pylori. Chúng tôi tiến hành đề tài này nhằm mục tiêu tìm hiểu mối liên quan kiểu gen iceA, cagA, vacA của $H$. pylori và mô bệnh học ở $B N$ ung thư dạ dày.

\section{II. ĐỐI TƯỢNG VÀ PHƯƠNG PHÁP NGHIÊN CỨU \\ 2.1. Đối tượng nghiên cứu}

Đối tượng nghiên cứu: gồm 91 bệnh nhân UTDD (nhóm bệnh) và 92 bệnh nhân viêm dạ dày mạn tính (nhóm chứng), được chọn trong số những người đã đến nội soi dạ dày và được chỉ định sinh thiết niêm mạc dạ dày để chẩn đoán xác định tại khoa Thăm dò chức năng, Bệnh viện Bạch Mai, từ tháng 7 năm 2015 đến tháng 5 nằm 2019.
Loại trừ những trường hợp sau: Bệnh nhân UTDD không còn chỉ định phẫu thuật; UTDD di căn từ cơ quan khác đến. Có ung thư cơ quan khác phối hợp với UTDD. DNA chiết tách từ mảnh sinh thiết không đảm bảo chất lượng. UTDD đã điều trị tia xạ, hóa chất, UTDD tái phát. Bệnh nhân mắc một số bệnh kèm theo: tiểu đường, huyết áp cao, xơ gan, suy thận...Bệnh nhân có rối loạn đông máu

2.2. Phương pháp nghiên cứu. Nghiên cứu tiến cứu, mô tả cắt ngang, có so sánh đối chứng.

Bệnh phẩm niêm mạc dạ dày để làm xét nghiệm urease test, mô bênh học (sử dụng kỹ thuật sinh thiết kẹp để lấy thêm 2 mảnh tại khối u để xét nghiệm mô bệnh học) và mẫu làm PCR xác định gene (Sinh thiết ở hang vị, phía bờ cong lớn, cách lỗ môn vị 2-3 cm cho vào ống chứa môi trường thạch, để trong ngăn đá và vận chuyển sang khoa Vi khuẩn, Viện Vệ sinh Dịch tễ trong ngày, cất trữ tại bình Ni tơ lỏng) theo hướng dẫn của hệ thống Sydney cập nhật (Dixon MF và cs, 1996).

Xét nghiệm mô bệnh học được tiến hành tại khoa Giải phẫu bênh - Bênh viên Bạch Mai. Tổn thương mô bệnh học được nhận định theo phân loại Lauren 1965 và WHO 2010

Khảo sát biểu lộ gen cagA, vacA và IceA bằng phương pháp phản ứng chuỗi polypmerase (Polymerase Chain Reaction - PCR) theo quy trình thường quy của Viện Karolinska, Thụy Điển. Mẫu sinh thiết ở bệnh nhân có test urease dương tính và $\mathrm{MBH}$ xác định là UTDD và VDD được đánh mã số cất trong bình ni tơ lỏng tại khoa Vi khuẩn, Viện Vệ sinh Dịch tễ TW được tiến hành phân tích bằng PCR trực tiếp.

\section{KẾT QUẢ NGHIÊN CỨU}

Từ 5/2017 đến 12/2019, chúng tôi đã tiến hành nghiên cứu 91 bệnh nhân ung thư dạ dày, 92 BN VDD

Bảng 3.1. Kiểu gen cagA, vacA $s / m$, iceA với thể MBH Lauren 1965

\begin{tabular}{|c|c|c|c|}
\hline \multirow{2}{*}{$\begin{array}{c}\text { Kiếu } \\
\text { gene }\end{array}$} & \multicolumn{2}{|c|}{ MBH Lauren 1965 } & \multirow{2}{*}{$\mathbf{p}$} \\
\cline { 2 - 3 } & Thế ruột & Thế lan tỏa & \\
\hline VacA m1 & $31(38,8)$ & $6(54,5)$ & 0,3 \\
\hline VacA m2 & $37(46,3)$ & $3(27,3)$ & 0,2 \\
\hline VacA s1 & $31(31,8)$ & $3(27,3)$ & 0,4 \\
\hline VacA s2 & $39(48,8)$ & $6(54,5)$ & 0,7 \\
\hline CagA & $59(73,8)$ & $6(54,5)$ & 0,2 \\
\hline iceA1 & $45(56,3)$ & $5(45,5)$ & 0,5 \\
\hline iceA2 & $9(11,3)$ & $1(9,1)$ & 0,8 \\
\hline
\end{tabular}

Nhận xét: Không có sự khác biệt các kiểu gen giữa thể ruột và thể lan tỏa ở bệnh nhân UTDD với $p>0,05$ 
Bảng 3.2. Liên quan giữa các gene CagA, VacA với MBH UTDD

\begin{tabular}{|c|c|c|c|c|c|}
\hline \multirow{2}{*}{ Gene } & \multicolumn{4}{|c|}{ Phân loại MBH theo WHO (n,\%) } & \multirow{2}{*}{ Tổng cộng } \\
\cline { 2 - 5 } & BH cao & BH vứa & BH kém & Thế Nhân & 65 \\
\hline CagA + & $2(3)$ & $21(32,4)$ & $36(55,4)$ & $6(9,2)$ & 68 \\
\hline VacA + & $1(1,3)$ & $26(33,3)$ & $42(53,8)$ & $9(11,5)$ & 78 \\
\hline
\end{tabular}

Nhận xét: Các BN UTDD có hình ảnh MBH biệt hóa kém chiếm tỳ lệ cao nhất ở cả hai nhóm CagA và VacA dương tính là $55,4 \%$ và $54,5 \%$. Ở nhóm $\mathrm{MBH}$ biệt hóa vừa, tỷ lệ $\mathrm{H}$. pylori mang gene CagA và VacA tương đương nhau (32,4\% và $32,5 \%)$.

Bảng 3.3. Môi liên quan giữa kiêu gene vacA s/m, iceA với MBH của UTDD

\begin{tabular}{|c|c|c|c|c|c|c|}
\hline \multirow{2}{*}{ Dang } & & \multicolumn{4}{|c|}{ Phân loại MBH theo WHO $(n, \%)$} & \multirow[b]{2}{*}{$\mathbf{n}$} \\
\hline & & BH cao & BH vừa & BH kém & Thế nhân & \\
\hline \multirow{2}{*}{ VacA m1 } & Dương tính & $1(2,7)$ & $12(32,4)$ & $18(48,6)$ & $6(16,2)$ & 37 \\
\hline & Am tính & $1(1,9)$ & $18(33,3)$ & $31(57,4)$ & $6(7,4)$ & 54 \\
\hline \multicolumn{7}{|c|}{$P=0,5$} \\
\hline \multirow{3}{*}{ VacA $\mathbf{m} 2$} & Dương tính & 0 & $14(35)$ & $23(57,5)$ & $3(7,5)$ & 40 \\
\hline & Am tính & $2(3,9)$ & $16(31,4)$ & $26(51)$ & $7(13,7)$ & 51 \\
\hline & \multicolumn{6}{|c|}{$\mathrm{P}=0,45$} \\
\hline \multirow[t]{3}{*}{ VacA s1 } & Dương tính & 0 & $11(32,4)$ & $20(58,8)$ & $3(8,8)$ & 34 \\
\hline & Ám tính & $2(3,5)$ & $19(33,3)$ & $29(50,9)$ & $7(12,3)$ & 57 \\
\hline & \multicolumn{6}{|c|}{$P=0,45$} \\
\hline \multirow[t]{3}{*}{ VacAs2 } & Dương tính & 0 & $11(32,4)$ & $20(58,8)$ & $3(8,8)$ & 34 \\
\hline & Am tính & $2(3,5)$ & $19(33,3)$ & $29(50,9)$ & $7(12,3)$ & 57 \\
\hline & \multicolumn{6}{|c|}{$P=0,64$} \\
\hline \multirow[t]{3}{*}{ iceA1 } & Dương tính & $2(4)$ & $16(32)$ & $27(54)$ & $5(10)$ & \\
\hline & Am tính & 0 & $14(34,1)$ & $22(53,7)$ & $5(12,2)$ & \\
\hline & \multicolumn{6}{|c|}{$P=0,5$} \\
\hline \multirow[t]{2}{*}{ iceA2 } & Dương tính & 0 & $4(40)$ & $5(50)$ & $1(10)$ & 10 \\
\hline & Am tính & $2(2,5)$ & $26(32,1)$ & $44(54,3)$ & $9(11,1)$ & 81 \\
\hline
\end{tabular}

Tỷ lệ nhóm UTDD có hình ảnh MBH biệt hóa kém mang kiểu gene vacA $\mathrm{m} 1$ là $48,6 \%, \mathrm{~m} 2$ $57,5 \%$, s1 $58,8 \%$, s2 $55,6 \%$, iceA1 là $55,6 \%$ và iceA2 là $54 \%$. Không có sự khác biệt các kiểu gen iceA1 và iceA2 giữa thể ruột và thể lan tỏa ở bệnh nhân UTDD với $p>0,05$. Không có sự khác biệt các kiểu gen iceA1 và iceA2 giữa thể tuyến ông và thể tế bào nhẫn ở bệnh nhân UTDD với $p>0,05$. Không hiên diện $H$. pylori có gen iceA ở $B N$ UTDD với $M B H$ thể tuyến chế nhày.

Kiểu gen iceA1 chiếm $55,6 \%$ ở nhóm MBH UTDD biệt hóa kém, $32 \%$ ở nhóm biệt hóa vừa. Kiểu gene iceA2 chiếm $50 \%$ ở nhóm biệt hóa kém và $40 \%$ ở nhóm biệt hóa vừa. Sự khác biệt giữa các kiểu gene $A 1$ và $A 2$ ở các nhóm $\mathrm{MBH}$ trên bệnh nhân UTDD ở nhóm biệt hóa vừa và kém có ý nghĩa thống kê với $p<0,05$.

\section{BÀN LUẬN}

Bằng việc xét nghiệm $\mathrm{PCR}$, nghiên cứu của chúng tôi tìm được gen CagA ở $71,4 \%$ các trường hợp UTDD, tỷ lệ này cao hơn ở nhóm VDD là $46,7 \%$, sự khác biệt này có ý nghĩa thống kê với $p<0,05$.

Kết quả này phù hợp với nghiên cứu của Trần Ngọc Ánh là $80,9 \%$ ở nhóm UTDD và $47,6 \%$ ở nhóm VDD. Một nghiên cứu khác của Lê Quý Hưng cũng cho kết quả $H$. pylori mang gen cagA tương đương với chúng tôi là $78,1 \%$ ở nhóm UTDD, với nhóm VDD là 44,2\% [6,7].

Nghiên cứu của chúng tôi thấp hơn một số nghiên cứu khác ở trong nước như Trần Thiện Trung là $100 \%$ ở nhóm UTDD và $92,3 \%$ ở nhóm VDD, Trần Đình Trí là $100 \%$. Mặc dù tỷ lệ của gen cagA có khác nhau với các nghiên cứu trong nước nhưng vẫn khẳng định được gen cagA là gen chính của $\mathrm{H}$. pylori có vai trò quan trọng trong cơ chế bệnh sinh gây UTDD[8].

Tỷ lệ nhóm UTDD có hình ảnh MBH biệt hóa kém mang kiểu gene vacA $m 1$ là $48,6 \%$, tỷ lệ nhóm $\mathrm{MBH}$ không mang kiểu gene này cũng chiếm tỷ lệ cao nhất là $57,4 \%$. Không có sự khác biệt giữa hai nhóm $\mathrm{MBH}$ có hay không có kiểu gene vacA $m 1$ với $p>0,05$. Tỷ lệ nhóm UTDD có hình ảnh $\mathrm{MBH}$ biệt hóa kém mang kiểu gen vacA s2 là $55,6 \%$, nhóm $\mathrm{MBH}$ biệt hóa vứa chiếm $28,9 \%$, tỷ lệ nhóm $\mathrm{MBH}$ không mang kiểu gen này cũng chiếm tỷ lệ cao nhất là $52,2 \%$. Không có sự khác biệt giữa hai nhóm $\mathrm{MBH}$ có hay không có kiểu gen vacA s2 với $p>0,05$. Theo Wei nghiên cứu yếu tố gen của $\mathrm{H}$. pylori với lâm sàng 
ở Hắc Long Giang, Trung Quốc thấy bệnh nhân UTDD có tỷ lệ vacA $m 1$ là $10,2 \%$ và vacA $m 2$ là $76,1 \%$ với $\mathrm{m} 2$ chiếm ưu thế tuyệt đối. Nghiên cứu của Khadir trên bệnh nhân UTDD ở Maroc có tỷ lệ $H$. pylori mang kiểu gen vacA s1 và s2 có kết quả tương tự như nghiên cứu của chúng tôi với tỷ lệ tương ứng là $43,8 \%$ và $54,8 \%$, nhưng tỷ lệ kiểu gen vacA s1 và s2 là $65,7 \%$ và 34,3 lại khác với kết quả chúng tôi.

Không có sự khác biệt các kiểu gen iceA1 và iceA2 giữa thể ruột và thể lan tỏa ở bệnh nhân UTDD với $p>0,05$. Không có sư khác biêt các kiểu gen iceA1 và iceA2 giữa thể tuyến ống và thể tế bào nhẫn ở bệnh nhân UTDD với $p>0,05$. Không có thể $\mathrm{MBH}$ tuyến chế nhày có $H$.pylori mang gene iceA. Kiểu gen iceA1 chiếm $54 \%$ ở nhóm MBH UTDD biệt hóa kém, 32\% ở nhóm biệt hóa vừa. Kiểu gene iceA2 chiếm $50 \%$ ở nhóm biệt hóa kém và $40 \%$ ở nhóm biệt hóa vừa. Sự khác biệt giữa các kiểu gene $A 1$ và $A 2$ ở các nhóm MBH trên bệnh nhân UTDD ở nhóm biệt hóa vừa và kém có ý nghĩa thống kê với $\mathrm{p}<0,05$. Ciftci I. H. và công sự (2011) phân tích 109 mẫu mô thu được 55 bệnh nhân VDDM và 54 bệnh nhân UTDD bệnh nhân ung thư dạ dày $(n=54)$ bi nhiễm H.pylori. Tỷ lê của gen iceA1 ở bênh nhân VDDM và UTDD là $51 \%(28 / 55)$ và $65 \%(35 / 54)$, trong khi tần số của gen iceA2 là $20 \%(11 / 55)$ và $28 \%(15 / 54)$, tương ứng. Sự khác biệt về tỷ lệ dương tính của kiểu gen iceA1 và iceA2 giữa các nhóm bệnh nhân không có ý nghĩa thống kê ( $p>0,05)$.

\section{KẾT LUÂN}

- Không có sự khác biêt các kiểu gen CagA, VacA giữa thể ruột và thể lan tỏa ở bệnh nhân
UTDD với $\mathrm{p}>0,05$.

- Không có mối liên quan giữa các týp CagA, VacA; các kiểu gen với các đặc điểm mô bệnh học của ung thư da dày theo WHO năm 2000.

- Sư khác biệt giữa các kiểu gen iceA1 và iceA2 ở các bệnh nhân ung thư da dày ở nhóm biệt hóa vừa và kém có ý nghĩa thống kê $(p<$ $0,05)$. Không có sự khác biệt các kiểu gen iceA1 và iceA2 với các đặc điểm mô bệnh học khác.

\section{TÀI LIÊU THAM KHẢO}

1. IARC (2014), Helicobacter pylori Eradication as a Strategy for Preventing Gastric Cancer. IARC Working Group Report Volume 8,p. 1-181.

2. Peek, R.M. and Crabtree JE. (2006). Helicobacter infection and gastric neoplasia. J. Pathol. 208: p. 233-248.

3. Sahara S, S.M., Vilaichone RK. (2012) Role of Helicobacter pylori cagA EPIYA motif and vacA genotypes for the development of gastrointestinal diseases in Southeast Asian countries: A metaanalysis. BMC infectious Diseases. 12(223).

4. Van Doorn LJ.(1998). Clinical relevance of the cagA, vacA, and iceA status of Helicobacter pylori. Gastroenterology. 115(1): p. 58-66.

5. Yamaoka Y.(1999). Relationship between Helicobacter pylori iceA, cagA, and vacA Status and Clinical Outcome: Studies in Four Different Countries. J Clin Microbiol. 37(7): p. 2274-2279.

6. Trân Ngọc Ánh (2006) Liên quan giữa các typ của vi khuân Helicobacter Pylori với bệnh lý ung thư dạ dày tai Viêt Nam. Y học lâm sàng, (4): 29-32.

7. Lê Quang Hưng, Hà Thị Minh Thi (2013). Nghiến cứu xác định kiểu gene CagA và VacA cua Helicobacter pylori ở bệnh nhân ung thư dạ dày. Tạp chí Y Dược học - Trường Đại học Y Dược Huế. 14: p. 118-125.

8. Trần Đình Trí (2016). Nghiên cứu hình thái mô bệnh học và các yếu tố độc lực cagA, vacA của Helicobacter pylori ở bênh nhân ung thư da dày. Tạp chí Y Dược học lâm sàng 108, 11(5), tr. 31-38

\section{ỨNG DUUNG CÔNG NGHÊ SỐ TRONG PHẪU THUÂ̂T CHİNH HÌNH XƯO'NG HÀM}

\section{TÓM TẮT.}

Phẫu thuật chỉnh hình xương là một phẫu thuật đặc biệt trong phẫu thuật hàm mặt có thể đem lại sự

\footnotetext{
${ }^{1}$ BV Đại học Y Hà Nội

2 Viện Đào tạo Răng-Hàm-Mặt, Đại học Y Hà Nội Chịu trách nhiệm chính: Nguyễn Trường Minh Email: nguyentruongminh@hmu.edu.vn Ngày nhận bài: 17.11.2020 Ngày phản biên khoa họ: 29.12.2020 Ngày duyệt bài: 8.01.2021
}

\section{Nguyễn Trường Minh ${ }^{1,2}$, Trương Mạnh Nguyên ${ }^{1,2}$, Đặng Triệu Hùng ${ }^{1,2}$, Lương Thị Thúy Phương ${ }^{1,2}$}

thay đổi toàn diện về cả thẩm mỹ và chức năng. Để đạt được sự thành công cần sự phối hợp chặt chẽ cửa phẫu thuật và chỉnh nha cũng như một kế hoạch phẫu thuật chính xác và toàn diện. Cùng với sự tiến bộ của công nghể số, phẫu thuật viên có thể lập kế hoạch, giả lập, tiển lượng quá trình phẫu thuật trước khi phẫu thuật thực sự. Đặc biệt trong một số trường hợp khó, việc có một kế hoạch hợp lý và ứng dụng công nghế số đóng một vai trò quan trong. Do đó mà những sai sót và khó khăn có thể tiên lượng trước và khắc phục trong quá trình phẫu thuật giúp nâng cao chất lượng điêu trị cho bệnh nhân. 